\title{
EFFECT OF GAMMA IRRADIATION ON in vitro BULBLETS STORAGE ABILITY AND GENETIC VARIATION OF SIX GARLIC GENOTYPES
}

(Received: 3.3.2010)

\author{
By \\ S. F. El-Sayed, A. A. Gharib, M. R. El-Shamy* and N. A. Abd Elwadod* \\ Department of Vegetable Crops, Faculty of Agriculture, Cairo University, Giza, Egypt. \\ *Horticulture Research Institute, Agricultural Research Center, Ministry of Agriculture, Giza, Egypt.
}

\begin{abstract}
This investigation was carried out in the Tissue Culture Laboratory of Potato and Vegetatively Propagated Crops, Vegetable Research Department, Agricultural Research Center (A.R.C.), during the period of 2005-2008 to study the effect of different doses of gamma rays (0, 3, 5, 8, 10, 12 and $14 \mathrm{~Gy})$ on the in vitro bulblets production from shoot basal plate ( $\mathrm{Sbp}$ ) explants of six garlic genotypes including three cultivars (Balady, American and Omani) and three clones (Sids-40, EgaSeed 1 and EgaSeed $_{2}$ ) on a bulblets production medium (MS $+120 \mathrm{~g} / \mathrm{l}$ sucrose $+5 \mathrm{~g} / \mathrm{l}$ activated charcoal $+0.1 \mathrm{mg}$ BA/l). The present investigation also studied the storage ability of the in vitro produced bulblets stored in a growth chamber at $25^{\circ} \mathrm{C}$ during four months of storage. The random amplified polumorphic DNA (RAPD) analysis confirmed the genetic background of irradiated garlic genotypes. All garlic genotypes were able to produce bulblets from Sbp explants. At the end of storage period (4 months) the bulblets were healthy and suitable for cultivation in the field. RAPD analysis indicated that the six garlic genotypes are different in the number of bands and this was attributed to the gamma ray doses.
\end{abstract}

Key words: bulblets, gamma ray doses, garlic, in vitro, RAPD analysis.

\section{INTRODUCTION}

Garlic (Allium sativum L.) is one of the most important crops that has a significant medicinal value, spice and food purposes within Alliaceae family and monocotyledonous plants (Block, 1985).

Garlic is propagated vegetatively by cloves and bulbils. It has low efficiency propagation in the field (Ebi et al., 2000). In vitro methods are suitable for overcoming the problems connected with conventional propagation by garlic cloves. One of the advantages of in vitro micropropagation is the higher rate of multiplication especially of the vegetatively propagated crops (Vuylsteke and Ortiz, 1996). The previous studies suggested that the basal part of the clove with or without shoot apex is a potent explant (Nagasawa and Finer, 1988 and Xeu et al., 1991). Tissue culture technique has also a high potential to improve garlic cultivation (Novak, 1990). In addition, radiation induced mutations have been extensively used for the improvement of crop plants. A combination of in vitro technique and radiation induced mutagenesis has been recorded to improve cultivars of the vegetatively propagated crops (Anonymous, 1986 and 1987 and Maluszynski et al., 1995). Recently, mutation techniques in combination with in vitro culture have become an important tool in improving garlic cultivars (Zhen, 1998). Garlic was generally classified as highly sensitive to gamma radiation above 50 Gy (Perez and Labrada, 1988). However, it was also reported that the critical dose of gamma rays depends on the genotype of garlic. The dose of $1 \mathrm{Kr}(10 \mathrm{~Gy})$ was a critical dose which the plant failed to survive until harvest and the doses of $0.2,0.3,0.4$, and 0.5 $\mathrm{Kr}$ (2, 3, 4 and $5 \mathrm{~Gy}$ ) were used to induce mutation forms in M1 (Sklyar, 1973). Moreover, as the gamma rays increased, the rate of shoot production declined. So, the low doses 1-3 Gy caused little differences between irradiated plants and the control in growth rate, while 12 Gy dose proved to be lethal for garlic (Dedul et al., 1985). Irradiation of garlic bulbs after 90 days from harvesting date with different doses of gamma rays $(1,3,6,9,12$, and $15 \mathrm{~Gy})$ induced different phenotypic variations (Alvarez and Delgado, 1996).

In vitro bulblet formation in garlic was an effective alternative method of the plant formation. It has many advantages over plantlets formation as reported earlier, e.g., bulblets are easy to manage and do not require special measurements for transferring to the soil (Nagakubo et al., 1993 and 1997; Mohamed- 
Yasseen et al., 1995; Zet et al., 1997 and Ucman et al., 1998). However, many factors were found affecting in vitro bulblets formation. For example, tissue culture media usually contains $3 \%$ sucrose, but for bulblets production media needs 6 to $12 \%$ sucrose, as bulblets are promoted and accelerated at these high concentrations (Nagakubo et al., 1993). High sugar concentration in vitro increased bulblets size in onion (Mohamed-Yasseen et al., 1992). In addition, activated charcoal (AC) has been reported to have beneficial effects on bulblets formation (Mohamed-Yasseen et al., 1994 and 1995). Also the exposure to low temperature $\left(4-5^{\circ} \mathrm{C}\right)$ for 60 days promoted garlic bulblets production in vitro (Nagakubo et al., 1993; Takagi and Qu, 1995 and Sumi et al., 2001). Moreover, the addition of BA increased the proliferation rate of a member of Allium spp. (Dunstan and Short, 1977; Hussey, 1978 and Mohamed-Yasseen et al., 1995). The most efficient medium for bulblets production was found to be MS $+120 \mathrm{~g} / \mathrm{l}$ sucrose $+5 \mathrm{~g} / \mathrm{l}$ charcoal $+0.1 \mathrm{mg} / \mathrm{l} \mathrm{BA}$ (Haque et al., 1997).

This investigation was conducted to study the effect of treating cloves of six garlic genotypes with different doses of gamma rays on:

1.In vitro bulblets formation.

2.The rate of bulblets and their storage ability at room temprature $\left(25 \pm 2{ }^{\circ} \mathrm{C}\right)$.

3.The genetic variation of plants after transferring the in vitro bulblets to the open field (through RAPD analysis).

\section{MATERIALS AND METHODS}

This investigation was carried out in the Tissue Culture Laboratory, of Potato and Vegetatively Propagated Crops, Vegetable Research Department, Agricultural Research Center (A.R.C.), during the period from 2005 to 2008. The present study included 3 main experiments, as follows:

\subsection{First experiment: Effect of gamma} irradiation on in vitro bulblets formation of six garlic genotypes

This part was carried out to investigate the effect of gamma ray doses on in vitro bulblets formation of six garlic genotypes including three cultivars (namely: Balady, American and Omani) as well as three clones namely: Sids-40 (an improved clone of Chinese origin.), EgaSeed ${ }_{1}$ and EgaSeed $_{2}$ (two improved clones imported from Asian Center for Research and Vegetable Development, Taiwan). Mature bulbs of the six garlic genotypes were kept at $4-5^{\circ} \mathrm{C}$ in a refrigerator for 60 days. After that, bulbs were irradiated with different doses of gamma rays. Balady cv. and the clone Sids- 40 were irradiated with $0,5,8,10,12$, and $14 \mathrm{~Gy}$. Due to the very low efficiency of bulblets production from this experiment, it was repeated with low doses of gamma ray viz. 0, 3, 5 and 8 Gy for the two clones EgaSeed $_{1}$ and EgaSeed 2 . Because of the relatively high efficiency of the dose of $8 \mathrm{~Gy}$, it was chosen thereafter to be the effective dose for mutation induction, and was repeated again with garlic cultivars,Balady, American and Omani as well as Sids-40 clone. The radiation treatments were conducted at the National Center for Radiation Research Technology, Nasr City, Cairo, Egypt.

After radiation, cloves were peeled and were rinsed with running tap water for $1 \mathrm{~h}$. Surface sterilization was conducted by immersing the cloves in $70 \%$ ethanol for $30 \mathrm{sec}$. then in $20 \%$ Clorox (commercial bleach containing 5.25\% sodium hypochlorite) with few drops of Tween20 , and continuous shaking for $20 \mathrm{~min}$. Cloves were rinsed several times with sterile distilled water. Shoot basal plate (shoot tip + stem disc) explants were isolated from irradiated cloves and used as explants. The shoot basal plate was divided longitudinally into 2-4 parts according to its size. Explants from one clove were cultured in jars containing $25 \mathrm{ml}$ of bulblets formation medium consisting of MS (Murashige and Skoog, $1962)+120 \mathrm{~g} / \mathrm{l}$ sucrose $+5 \mathrm{~g} / \mathrm{l}$ charcoal +0.1 mg/l BA (Haque et al., 1997). Ten replicates (10 jars) were used for each dose of gamma rays.

\section{Data were recorded as follows:}

1.Number of bulblets/jar after 30, 35, 40 and 60 days from culture.

2.Bulblets diameter, and fresh weight after two months from culture.

2.2. Second experiment: Effect of gamma irradiation on the storage ability of in vitro produced bulblets of six garlic genotypes.

After taking data of the first experiment, garlic bulblets of the six garlic genotypes were immersed in a solution containing of $1 \mathrm{~g}$ Benlite + $1 \mathrm{~g}$ Resolex1000 $\mathrm{ml}$ water for $15 \mathrm{~min}$, then dried with towels. The bulblets were individually separated and the fresh weight was recorded. Bulblets were left for 1-2 days in open air then were incubated in a growth chamber at $25^{\circ} \mathrm{C} \pm 2$ ${ }^{\circ} \mathrm{C}$.

Bulblets weight loss percentage was recorded after one, two, three and four months from the beginning of storage.

2.3. Third experiment: Effect of gamma irradiation, on the genetic variations of the in vitro produced bulblets of six genotypes

In vitro bulblets irradiated with 8 Gy of gamma rays as well as unirradiated control (0 Gy) 
of the six garlic genotypes (cvs. Balady, American and Omani as well as Sids-40, EgaSeed ${ }_{1}$ and EgaSeed $_{2}$ clones) were subjected to the random amplified polymorphic DNA analysis (RAPD) using primer No. 5' AGG TGA CCG $\mathrm{T} 3^{\prime}$ to determine the genetic variations among them. Isolations of DNA from irradiated and unirradiated control plants were carried out according to the protocol described by Williams et al. (1990).

All experiments were arranged in factorial completely randomized design. All data were subjected for the proper analysis according to Mstatc software program (Michigan State University, East Lansing, MI, USA). Probabilities of significance among treatments and means were compared with least significance L.S.D $(\mathrm{P} \leq 0.05)$ was used to compare means within and among treatments according to Gomez and Gomez (1984).

\section{RESULTS}

3.1. Effect of gamma irradiation on in vitro bulblets formation of six garlic genotypes

3.1.1. Effect of gamma irradiation $(0,5,8,10$, 12 and $14 \mathrm{~Gy}$ ) on in vitro bulblets formation of the two garlic genotypes (cultivar Balady and Sids-40 clone)

3.1.1.1. Number of bulblets/jar $(30,35,40$ and 60 days after culture)

The effects of gamma ray doses viz, $0,5,8$, 10,12 or 14 Gy and days after culture $(30,35,40$ or 60 days) on the number of bulblets/jar of the two garlic genotypes (cv.Balady and Sids-40 clone) are present in Table (1). There were no significant differences between the two genotypes in the number of bulblets per jar.

Concerning the effect of gamma rays on this character, there was no significant difference between the dose of $5 \mathrm{~Gy}$ and the unirradiated control (0 Gy), as well as between 10 Gy and 12 Gy. The highest dose (14 Gy) showed the lowest number of bulblets/jar. With the passing of time, the number of bulblets per jar was increased in both genotypes to reach the maximum 40 days after culture, where they had the same number of bulblets per jar. There were no further increments in the number of bulblets after this period in both genotypes. Besides, there were no significant differences within each genotype concerning this character after $30,35,40$ and 60 days after culture. The interaction among the two genotypes, gamma doses and the progress of time (Gn. X Gy. $X \mathrm{D})$ was significant. The highest numbers of bulblets were produced in both genotypes at 40 or 60 days after culture due to irradiation with the dose of $5 \mathrm{~Gy}$, whereas the lowest ones were recorded at 30 days after culture in Sids-40 clone subjected to the high doses of gamma rays, i.e., 10,12 or $14 \mathrm{~Gy}$.

\subsubsection{Bulblets diameter and weight 2 months after culture.}

Results listed in Table (2) show that Sids-40 clone produced larger bulblet diameter as well as heavier bulblet fresh weight than the cultivar Balady.

Regarding gamma doses, the lowest dose of gamma ray $(5 \mathrm{~Gy})$ produced significantly larger bulblet diameter and heavier weight compared to the unirradiated control, or to gamma rays at 8, 10, 12 and $14 \mathrm{~Gy}$. This also was true within each genotype. The interaction showed that the largest bulblet diameter and the heaviest bulblet weight were produced by Sids-40 clone irradiated with 5 Gy, whereas the opposite was recorded in the cultivar Balady irradiated with $14 \mathrm{~Gy}$.

3.1.2. Effect of gamma irradiation $(0,3,5$, and $8 \mathrm{~Gy}$ ) on in vitro bulblets formation of two garlic genotypes (EgaSeed 1 and EgaSeed $_{2}$ clones)

\subsubsection{Number of bulblets/ jar $(30,35,40$ and 60 days after culture)}

The effects of gamma ray doses and days after culture on the number of bulblets per jar of the two garlic genotypes are shown in Table (3). In this concern, there were no significant differences between the two genotypes in the number of bulblets/jar.

On the other hand, the two doses of 3 and 5 Gy significantly increased the number of bulblets per jar as compared with the unirradiated control. In contrast, the high dose of gamma ray ( $8 \mathrm{~Gy}$ ) significantly decreased this character. The same trend was true within each genotype. With the progress of time, the number of bulblets per jar was increased in both genotypes. The interaction among the two genotypes, doses of gamma rays and the days after culture i.e., Gn. X Gy. X D. was significant. The highest number of bulblets per jar was recorded 40 days after culture in EgaSeed $_{1}$ clone irradiated with $5 \mathrm{~Gy}$, whereas the lowest one was recorded in EgaSeed $_{2}$ clone irradiated with 8 Gy, 30 days after culture.

\subsubsection{Bulblet diameter and weight, 2 months after culture}

As shown in Table (4), there were no significant differences between the two genotypes, namely Egaseed $_{1}$, and Egaseed $_{2}$ in bulblet diameter and weight.

Treating garlic before culturing with $3 \mathrm{~Gy}$ of gamma rays led significantly to producing larger and heavier bulblets in vitro than the untreated control. In contrast, the highest dose of gamma rays i.e., 8 Gy significantly decreased 
Table (1): Effect of gamma irradiation and days after culture on the number of bulblets/jar resulting from culturing of shoot basal plate of two garlic genotypes (Balady and Sids-40 clone).

\begin{tabular}{|c|c|c|c|c|c|c|c|c|}
\hline \multirow{3}{*}{$\begin{array}{l}\text { Days } \\
\text { after } \\
\text { culture }\end{array}$} & \multirow{3}{*}{ Genotypes } & \multicolumn{6}{|c|}{ Number of bulblets/jar } & \multirow{3}{*}{ Mean } \\
\hline & & \multicolumn{6}{|c|}{ Gamma ray doses (Gy) } & \\
\hline & & $\mathbf{0}$ & 5 & 8 & 10 & 12 & 14 & \\
\hline \multirow{3}{*}{30} & Balady & 2.40 & 2.60 & 2.20 & 2.20 & 2.20 & 2.00 & 2.27 \\
\hline & Sids-40 & 2.60 & 2.80 & 2.60 & 2.00 & 2.00 & 2.00 & 2.33 \\
\hline & Mean & 2.50 & 2.70 & 2.40 & 2.10 & 2.10 & 2.00 & 2.32 \\
\hline \multirow{3}{*}{35} & Balady & 3.60 & 4.00 & 3.00 & 2.60 & 2.60 & 2.00 & 2.97 \\
\hline & Sids-40 & 3.60 & 3.40 & 3.00 & 2.80 & 2.60 & 2.40 & 2.97 \\
\hline & Mean & 3.60 & 3.70 & 3.00 & 2.70 & 2.60 & 2.20 & 2.97 \\
\hline \multirow{3}{*}{40} & Balady & 4.60 & 4.80 & 3.80 & 3.20 & 2.60 & 2.20 & 3.53 \\
\hline & Sids-40 & 4.40 & 4.40 & 3.60 & 3.20 & 3.20 & 3.60 & 3.73 \\
\hline & Mean & 4.50 & 4.60 & $\mathbf{3 . 7 0}$ & 3.20 & 2.90 & 2.40 & 3.55 \\
\hline \multirow{6}{*}{60} & Balady & 4.60 & 4.80 & 3.80 & 3.20 & 2.60 & 2.20 & 3.53 \\
\hline & Sids-40 & 4.40 & 4.40 & 3.60 & 3.20 & 3.20 & 3.60 & 3.73 \\
\hline & Mean & 4.50 & 4.60 & 3.70 & 3.20 & 2.90 & 2.40 & 3.55 \\
\hline & Balady & 3.80 & 4.05 & 3.22 & 2.83 & 2.50 & 2.10 & 3.08 \\
\hline & Sids-40 & 3.75 & 3.75 & 3.20 & 2.80 & 2.75 & 2.40 & 3.11 \\
\hline & Mean & 3.78 & 3.90 & 3.21 & 2.82 & 2.63 & 2.25 & \\
\hline \multicolumn{2}{|c|}{ LSD $_{0.05}$ for } & & & & & & & \\
\hline \multicolumn{2}{|c|}{ Genotypes (Gn.) } & & NS & & \multicolumn{2}{|c|}{ Gn. X Gy. } & 0.47 & \\
\hline \multicolumn{2}{|c|}{ Gamma rays (Gy.) } & & 0.33 & & \multicolumn{2}{|c|}{ Gn. X D. } & 0.38 & \\
\hline \multicolumn{2}{|c|}{ Days (D.) } & & 0.27 & & \multicolumn{2}{|c|}{ Gy. X D. } & 0.66 & \\
\hline \multicolumn{2}{|c|}{ Gn. X Gy. X D. } & & 0.93 & & & & & \\
\hline
\end{tabular}

Table (2): Effect of gamma irradiation on bulblet diameter and fresh weight resulting from culturing of shoot basal plate of the two garlic genotypes (Balady and Sids-40 clone), 2 months after culture.

\begin{tabular}{|c|c|c|c|c|c|c|}
\hline \multirow{2}{*}{$\begin{array}{c}\text { Gamma } \\
\text { doses } \\
(\mathbf{G y})\end{array}$} & \multicolumn{2}{|c|}{ Bulblet diameter (mm) } & \multirow{2}{*}{ Mean } & \multicolumn{2}{|c|}{ Bulblet fresh weight (g). } & \multirow{2}{*}{ Mean } \\
\hline & Balady & Sids-40 & & Balady & Sids-40 & \\
\hline 0 & 7.81 & 9.23 & 8.52 & 0.70 & 1.40 & 1.05 \\
\hline 5 & 8.82 & 9.60 & 9.41 & 0.77 & 1.73 & 1.25 \\
\hline 8 & 7.73 & 8.76 & 8.25 & 0.64 & 1.31 & 0.98 \\
\hline 10 & 7.12 & 6.37 & 6.75 & 0.59 & 1.02 & $\mathbf{0 . 8 1}$ \\
\hline 12 & 3.87 & 6.00 & 4.94 & 0.34 & 0.43 & 0.39 \\
\hline 14 & 3.77 & 4.28 & 2.33 & 0.32 & 0.40 & 0.36 \\
\hline Mean & 5.95 & 7.31 & & 0.56 & 1.08 & \\
\hline \multicolumn{3}{|c|}{ LSD $_{0.05}$ for } & & & & \\
\hline \multicolumn{3}{|c|}{ Genotypes (Gn.) } & 0.41 & & & 0.12 \\
\hline \multicolumn{3}{|c|}{ Gamma rays (Gy.) } & 0.71 & & & 0.21 \\
\hline \multicolumn{3}{|c|}{ Gn. X Gy. } & 0.99 & & & 0.30 \\
\hline
\end{tabular}


Effect of gamma irradiation on in vitro...

Table (3) Effect of gamma irradiation and days after culture (30, 35, 40 and 60 days) on the number of bulblets/jar resulting from culturing of shoot basal plate of the two garlic genotypes

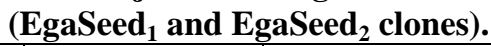

\begin{tabular}{|c|c|c|c|c|c|c|}
\hline \multirow{3}{*}{$\begin{array}{c}\text { Days } \\
\text { after } \\
\text { culture }\end{array}$} & \multirow{3}{*}{$\begin{array}{c}\text { Genotypes } \\
\text { (clones) }\end{array}$} & \multicolumn{4}{|c|}{ Number of bulblets/jar } & \multirow{3}{*}{ Mean } \\
\hline & & \multicolumn{4}{|c|}{ Gamma ray doses (Gy) } & \\
\hline & & $\mathbf{0}$ & 3 & 5 & 8 & \\
\hline \multirow{2}{*}{30} & EgaSeed $_{1}$ & 2.10 & 2.12 & 2.60 & 1.40 & 2.06 \\
\hline & EgaSeed $_{2}$ & 1.45 & 1.85 & 2.50 & 1.35 & 1.79 \\
\hline & Mean & 1.78 & 1.99 & 2.55 & 1.38 & 1.93 \\
\hline \multirow{2}{*}{35} & EgaSeed $_{1}$ & 3.80 & 3.85 & 4.00 & 2.00 & 3.41 \\
\hline & EgaSeed $_{2}$ & 2.10 & 2.20 & 3.20 & 2.00 & 2.38 \\
\hline & Mean & 2.90 & 3.03 & 3.60 & 2.05 & 2.90 \\
\hline \multirow{2}{*}{40} & EgaSeed $_{1}$ & 4.24 & 4.75 & 5.10 & 3.15 & 4.31 \\
\hline & EgaSeed $_{2}$ & 3.90 & 4.40 & 4.60 & 3.20 & 4.03 \\
\hline & Mean & 4.07 & 4.58 & 4.85 & 3.18 & 4.17 \\
\hline \multirow{6}{*}{60} & EgaSeed $_{1}$ & 4.24 & 4.75 & 5.10 & 3.15 & 4.31 \\
\hline & EgaSeed $_{2}$ & 3.90 & 4.40 & 4.60 & 3.20 & 4.03 \\
\hline & Mean & 4.07 & 4.58 & 4.85 & 3.18 & 4.17 \\
\hline & EgaSeed $_{1}$ & 3.38 & 3.87 & 4.20 & 1.85 & 3.33 \\
\hline & EgaSeed $_{2}$ & 2.84 & 3.21 & 3.73 & 2.44 & 3.05 \\
\hline & Mean & 3.11 & 3.54 & 3.97 & 2.15 & \\
\hline \multicolumn{7}{|c|}{ LSD $_{0.05}$ for } \\
\hline \multicolumn{2}{|c|}{ Genotypes (Gn.) } & NS & & \multicolumn{2}{|c|}{ Gn. X Gy. } & 0.48 \\
\hline \multicolumn{2}{|c|}{ Gamma rays (Gy.) } & 0.34 & & \multicolumn{2}{|c|}{ Gn. X D. } & 0.48 \\
\hline \multicolumn{2}{|c|}{ Days (D.) } & 0.34 & & \multicolumn{2}{|l|}{ Gy. X D. } & 0.68 \\
\hline \multicolumn{2}{|c|}{ Gn. X Gy. X D. } & 0.97 & & & & \\
\hline
\end{tabular}

Table (4): Effect of gamma irradiation bulblets diameter and fresh weight resulting from culturing of shoot basal plate of two garlic genotypes $\left(\operatorname{EgaSeed}_{1}\right.$ and EgaSeed $_{2}$ clones), 2 months after culture.

\begin{tabular}{|c|c|c|c|c|c|c|}
\hline \multirow{2}{*}{$\begin{array}{l}\text { Gamma } \\
\text { doses (Gy) }\end{array}$} & \multicolumn{2}{|c|}{ Bulblet diameter (mm) } & \multirow{2}{*}{ Mean } & \multicolumn{2}{|c|}{ Bulblet fresh weight (g) } & \multirow{2}{*}{ Mean } \\
\hline & EgaSeed $_{1}$ & EgaSeed $_{1}$ & & EgaSeed $_{1}$ & EgaSeed $_{1}$ & \\
\hline 0 & 8.14 & 8.23 & 8.18 & 1.09 & 1.17 & 1.13 \\
\hline 3 & 8.79 & 8.97 & 8.88 & 1.44 & 1.50 & 1.47 \\
\hline 5 & 8.58 & 8.73 & 8.66 & 1.20 & 1.12 & 1.20 \\
\hline 8 & 7.01 & 7.43 & 7.22 & 1.05 & 1.11 & 1.08 \\
\hline Mean & 8.13 & 8.34 & & 1.19 & 1.26 & \\
\hline \multicolumn{7}{|c|}{ LSD $_{0.05}$ for } \\
\hline \multicolumn{3}{|c|}{ Genotypes (Gn.) } & NS & & & NS \\
\hline \multicolumn{3}{|c|}{ Gamma rays (Gy.) } & 0.53 & & & 0.31 \\
\hline \multicolumn{3}{|c|}{ Gn. X Gy. } & 0.74 & & & NS \\
\hline
\end{tabular}

bulblet diameter and relatively decreased bulblet weight. The stimulative effect of 3 Gy was significant regarding bulblet diameter of Egaseed $_{2}$ clone. The reduction effect of 8 Gy dose was remarkable on the bulblet diameter of both genotypes. The largest bulblet diameter was produced in Egaseed $_{2}$ irradiated with $3 \mathrm{~Gy}$, whereas the lowest bulblet diameter was recorded in Egaseed $_{1}$ due to radiation with the dose of $8 \mathrm{~Gy}$. 3.1.3. Effect of gamma irradiation ( 0 and $8 \mathrm{~Gy}$ ) on in vitro bulblet formation of four garlic genotypes (Balady, American and Omani as well as Sids-40 clone)

3.1.3.1. Number of bulblets jar $(30,35,40$ and 60 days after culture)

As shown in Table (5), there were no significant differences among the four genotypes in the number of bulblets per jar.

Radiation with gamma rays at 8 Gy significantly reduced the number of bulblets per jar. An increment in the number of bulblets was noticed with the progress of time till 40 days after culture. Thereafter, no further significant effect for 
the time on the number of bulblets was recorded. Accordingly, no more bulblets were produced after 40 days from culture. The interaction of $\mathrm{Gn}$. $\mathrm{X}$ Gy. X D. was significant. The highest number of bulblets per jar was produced by the unirradiated control Sids- 40 clone at 40 or 60 days after culture, whereas the lowest one was found in either the unirradiated control or in irradiated garlic cv. Balady at 30 days after culture.

\subsubsection{Bulblets diameter and weight 2 months after culture}

The effect of gamma doses on the bulblet diameter and weight of the four garlic genotypes viz. (cvs. Balady, American and Omani, as well as Sids-40 clone) 2 months after culture are shown in Table (6). In this concern, cv. Balady had significantly lower bulblet diameters and weights as compared with the other three genotypes. No significant differences were detected among the other three genotypes in their bulblet diameter and weight.

Generally, the dose of 8 Gy significantly reduced both bulblet diameter and weight in all genotypes. However, this reduction was significant regarding bulblet diameter as well as bulblet weight in cultivar B. The largest bulblet diameter and the heaviest weight were produced by unirradiated control ( 0 Gy) of Sids-40 clone, whereas the lowest value was recorded in cv. Balady irradiated with 8 Gy.

3.2. Effect of gamma irradiation $(0,5,8$ and 10 Gy) on the storage ability of in vitro produced bulblets of six garlic genotypes.

3.2.1. Bulblets weight loss (\%) of two garlic genotypes (cultivar Balady and Sids-40 clone) during four months of storage

It was clear from the data recorded in Table (7), that garlic cv. Balady significantly recorded a lower value of bulblet weight loss than Sids-40 clone. Such difference was not significant within each month. On the other hand, the highest dose of gamma ray (10 Gy) recorded the highest value of bulblets loss in both genotypes, whereas the dose of 8 Gy recorded generally the lowest one. Nevertheless, such desirable effect of 8 Gy dose in reducing bulblet weight loss was not significantly within each genotype, as compared with unirradiated control. With the progress of storage bulblet weight losses were increased to reach their maximum value after 4 months of storage in both genotypes. Generally, the lowest weight loss was recorded in garlic cv.Balady irradiated with 8 Gy after one month of storage, while the highest one was recorded in Sids-40 clone treated with 10 Gy four months after storage.
3.2.2. Bulblets weight loss (\%) of the two garlic genotypes $\left(\right.$ EgaSeed $_{1}$ and EgaSeed $_{2}$ clones) during four months of storage

As shown in Table (8), there were no significant differences in the percentage of bulblet weight loss between the two genotypes after one, two, three or four months of storage.

With regard to gamma doses, the highest dose ( $8 \mathrm{~Gy}$ ) was the best one for bulblet storage, as this dose gave a lower bulblet weight loss compared with the other three doses, and the opposite was true regarding the unirradiated control (0 Gy). No significant differences were obtained between the low doses of gamma ray (3 and $5 \mathrm{~Gy}$ ). With increasing the time of storage more bulblet weight loss was recorded in both genotypes of garlic. The interaction among genotypes, gamma dose and storage period indicated that the lowest bulblet weight loss was shown in $\mathrm{EgaSeed}_{2}$ treated with 8 Gy one month after storage $(20.2 \%)$, while the highest value was found in unirradiated EgaSeed $_{1}$ four months after storage $(63.1 \%)$.

3.2.3. Bulblets weight loss $(\%)$ of four garlic genotypes (Balady, American and Omani and Sids-40 clone) during four months of storage

Results presented in Table (9), clearly show that the weight loss percentage was lower in $\mathrm{cv}$. Balady as compared to the other three genotypes. There were no significant differences among

American, Omani and Sids-40 in this regard.

As for gamma doses, the dose of 8 Gy significantly reduced bulblet weight loss than the unirradiated control.

With the progress of storage time, the percentage of bulblet weight loss was increased and there were significant differences among the four storage periods. The three other interactions showed that the lowest bulblet weight loss was recorded in cv Balady irradiated with 8 Gy after one month of storage, while the highest one was found in unirradiated Sids-40 four months after storage.

3.3. Effect of gamma irradiation, on the genetic variation of in vitro produced bulblets of six garlic genotypes

Data in Table (10) and Plate (1) declare that the RAPD analyses (using the primer 5' AGG TGA CCG T 3') showed different new bands. The new bands of the six garlic genotypes were completely different from their control except for EgaSeed $_{1}$ and EgaSeed 2 clones and cv. Omani where some bands were similar to their control. 
Table (5): Effect of gamma irradiation and days after culture on the number of bulblets/jar resulting from culturing of shoot basal plate of four garlic genotypes (Balady, American, and Omani as well as Sids-40 clone).

\begin{tabular}{|c|c|c|c|c|c|c|}
\hline \multirow{3}{*}{$\begin{array}{l}\text { days } \\
\text { after } \\
\text { culture }\end{array}$} & \multirow{3}{*}{$\begin{array}{c}\text { Gamma } \\
\text { doses (Gy) }\end{array}$} & \multicolumn{4}{|c|}{ Genotypes } & \multirow[b]{2}{*}{ Mean } \\
\hline & & Balady & American & Omani & Sids-40 & \\
\hline & & \multicolumn{4}{|c|}{ Number of bulblets/jar } & \\
\hline \multirow{3}{*}{30} & $\mathbf{0}$ & 1.40 & 1.80 & 1.80 & 1.50 & 1.63 \\
\hline & 8 & 1.40 & 1.65 & 1.55 & 1.45 & 1.50 \\
\hline & Mean & 1.40 & 1.73 & 1.68 & 1.48 & 1.57 \\
\hline \multirow{3}{*}{35} & $\mathbf{0}$ & 2.80 & 3.80 & 3.00 & 2.80 & 3.05 \\
\hline & 8 & 2.40 & 2.65 & 2.20 & 2.40 & 2.35 \\
\hline & Mean & 2.60 & 3.23 & 2.60 & 2.60 & 2.70 \\
\hline \multirow{3}{*}{40} & $\mathbf{0}$ & 4.50 & 4.40 & 4.80 & 5.40 & 4.78 \\
\hline & 8 & 3.50 & 3.95 & 3.25 & 3.45 & 3.54 \\
\hline & Mean & 4.00 & 4.18 & 4.03 & 3.93 & 4.16 \\
\hline \multirow{6}{*}{60} & $\mathbf{0}$ & 4.50 & 4.40 & 4.80 & 5.40 & 4.78 \\
\hline & 8 & 3.50 & 3.95 & 3.25 & 3.45 & 3.54 \\
\hline & Mean & 4.00 & 4.18 & 4.03 & 3.93 & 4.16 \\
\hline & $\mathbf{0}$ & 3.30 & 3.60 & 3.60 & 3.78 & 3.57 \\
\hline & 8 & 2.70 & 3.05 & 2.56 & 2.69 & 2.75 \\
\hline & Mean & 3.00 & $\mathbf{3 . 3 3}$ & 3.09 & 3.24 & \\
\hline \multicolumn{7}{|c|}{ LSD $_{0.05}$ for } \\
\hline \multicolumn{2}{|c|}{ Genotypes (Gn.) } & NS & & \multicolumn{2}{|l|}{ Gn. X Gy. } & 0.60 \\
\hline \multicolumn{2}{|c|}{ Gamma rays (Gy.) } & 0.30 & & \multicolumn{2}{|l|}{ Gn. X D. } & 0.84 \\
\hline \multicolumn{2}{|c|}{ Days (D.) } & 0.42 & & \multicolumn{2}{|l|}{ Gy. X D. } & 0.60 \\
\hline \multicolumn{2}{|c|}{ Gn. X Gy. X D. } & 1.19 & & & & \\
\hline
\end{tabular}

Table (6): Effect of gamma irradiation on bulblet diameter and fresh weight resulting from culturing of shoot basal plate of four garlic genotypes Balady (B), American (A) and Omani (Om) as well as Sids-40 (S) clones)], 2 months after culture.

\begin{tabular}{|c|c|c|c|c|c|c|c|c|c|c|}
\hline \multirow{2}{*}{$\begin{array}{c}\text { Gamma } \\
\text { doses (Gy) }\end{array}$} & \multicolumn{4}{|c|}{ Bulblet diameter (mm) } & \multirow{2}{*}{ Mean } & \multicolumn{4}{|c|}{ Bulblet fresh weight (g) } & \multirow{2}{*}{ Mean } \\
\hline & B & $\mathbf{A}$ & Om & $\mathbf{S}$ & & B & $\mathbf{A}$ & Om & $\mathbf{S}$ & \\
\hline $\mathbf{0}$ & 7.64 & 8.61 & 8.40 & 8.79 & 8.32 & 1.03 & 1.28 & 1.25 & 1.29 & 1.21 \\
\hline 8 & 5.94 & 8.11 & 7.29 & 8.45 & 7.45 & 0.59 & 1.07 & 0.99 & 1.10 & 0.94 \\
\hline Mean & 6.70 & 8.36 & 7.85 & 8.62 & & 0.81 & 1.18 & 1.10 & 1.20 & \\
\hline \multicolumn{11}{|c|}{ LSD $_{0.05}$ for } \\
\hline \multicolumn{5}{|c|}{ Genotypes (Gn.) } & 0.82 & & & & & 0.30 \\
\hline \multicolumn{5}{|c|}{ Gamma rays (Gy.) } & 0.58 & & & & & 0.29 \\
\hline \multicolumn{5}{|c|}{ Gn.. X Gy. } & 1.16 & & & & & 0.50 \\
\hline
\end{tabular}


Table (7): Percentage of bulblet weight loss during storage at $25^{\circ} \mathrm{C}$ of the two garlic genotypes (Balady and Sids-40 clone) as affected by gamma ray doses.

\begin{tabular}{|c|c|c|c|c|c|c|}
\hline \multirow{3}{*}{$\begin{array}{l}\text { Months } \\
\text { after } \\
\text { culture }\end{array}$} & \multirow{3}{*}{ Genotypes } & \multicolumn{4}{|c|}{ Bulblets weight loss (\%) } & \multirow{3}{*}{ Mean } \\
\hline & & \multicolumn{4}{|c|}{ Gamma ray doses } & \\
\hline & & O Gy. & 5 Gy. & 8 Gy. & 10 Gy. & \\
\hline \multirow{3}{*}{$\begin{array}{c}\text { One } \\
\text { month }\end{array}$} & Balady & 20.8 & 17.3 & 15.7 & 27.5 & 20.4 \\
\hline & Sids-40 & 22.8 & 20.8 & 17.1 & 34.9 & 23.9 \\
\hline & Mean & 21.8 & 19.1 & 16.4 & 31.2 & 22.1 \\
\hline \multirow{3}{*}{$\begin{array}{c}\text { Two } \\
\text { months }\end{array}$} & Balady & 30.5 & 27.8 & 25.6 & 39.7 & 30.9 \\
\hline & Sids-40 & 34.1 & 29.8 & 28.4 & 46.1 & 34.5 \\
\hline & Mean & 32.3 & 28.9 & 26.8 & 42.9 & 32.7 \\
\hline \multirow{3}{*}{$\begin{array}{c}\text { Three } \\
\text { months }\end{array}$} & Balady & 37.0 & 36.1 & 33.1 & 51.7 & 39.5 \\
\hline & Sids-40 & 42.0 & 39.8 & 36.5 & 59.2 & 44.4 \\
\hline & Mean & 39.5 & 38.0 & 34.8 & 55.5 & 41.9 \\
\hline \multirow{6}{*}{$\begin{array}{c}\text { Four } \\
\text { months }\end{array}$} & Balady & 43.7 & 43.7 & 41.0 & 58.3 & 46.7 \\
\hline & Sids-40 & 50.7 & 45.1 & 44.2 & 60.3 & 52.6 \\
\hline & Mean & 47.2 & 44.4 & 42.6 & 50.1 & 49.6 \\
\hline & Balady & 32.4 & 31.2 & 28.9 & 44.3 & 34.3 \\
\hline & Sids-40 & 37.4 & 33.9 & 31.5 & 50.1 & 38.2 \\
\hline & Mean & 34.9 & 32.6 & 30.2 & 47.2 & \\
\hline \multicolumn{7}{|c|}{ LSD $_{0.05}$ for } \\
\hline \multicolumn{2}{|c|}{ Genotypes (Gn.) } & 2.3 & \multicolumn{2}{|c|}{ Gn. X Gy. } & 6.9 & \\
\hline \multicolumn{2}{|c|}{ Gamma rays (Gy.) } & 4.2 & \multicolumn{2}{|c|}{ Gy. X Mos. } & 11.1 & \\
\hline \multicolumn{2}{|c|}{ Months (Mos.) } & 4.0 & \multicolumn{2}{|c|}{ Gn. X Mos. } & 6.3 & \\
\hline \multicolumn{2}{|c|}{ Gn. X Gy. Mos. } & 17.7 & & & & \\
\hline
\end{tabular}

Table(8): Percentage of bulblet weight loss during storage at $25^{\circ} \mathrm{C}$ of the two garlic genotypes (EgaSeed ${ }_{1}$ and EgaSeed ${ }_{2}$ clones) as affected by gamma ray doses.

\begin{tabular}{|c|c|c|c|c|c|c|}
\hline \multirow{3}{*}{$\begin{array}{l}\text { Months } \\
\text { after } \\
\text { culture }\end{array}$} & & \multicolumn{4}{|c|}{ Bulblets weight loss (\%) } & \multirow{3}{*}{ Mean } \\
\hline & Genotypes & \multicolumn{4}{|c|}{ Gamma ray doses (Gy) } & \\
\hline & & $\mathbf{0}$ & 3 & 5 & 8 & \\
\hline \multirow{3}{*}{ Month } & EgaSeed $_{1}$ & 31.2 & 26.1 & 24.7 & 21.3 & 25.8 \\
\hline & EgaSeed $_{2}$ & 28.2 & 22.6 & 21.5 & 20.2 & 23.1 \\
\hline & Mean & 29.7 & 24.4 & 23.1 & 20.7 & 24.5 \\
\hline \multirow{3}{*}{$\begin{array}{c}\text { Two } \\
\text { months }\end{array}$} & EgaSeed $_{1}$ & 42.7 & 40.6 & 39.6 & 35.5 & 39.6 \\
\hline & EgaSeed $_{2}$ & 40.2 & 39.7 & 37.9 & 32.6 & 37.6 \\
\hline & Mean & 41.5 & 40.2 & 38.8 & 34.0 & 38.6 \\
\hline \multirow{3}{*}{$\begin{array}{l}\text { Three } \\
\text { months }\end{array}$} & EgaSeed $_{1}$ & 54.8 & 52.7 & 45.7 & 39.3 & 48.1 \\
\hline & EgaSeed $_{2}$ & 53.2 & 46.2 & 44.0 & 35.9 & 44.8 \\
\hline & Mean & 54.0 & 49.4 & 44.8 & 37.6 & 46.5 \\
\hline \multirow{6}{*}{$\begin{array}{c}\text { Four } \\
\text { months }\end{array}$} & EgaSeed $_{1}$ & 63.1 & 60.4 & 53.4 & 48.2 & 56.3 \\
\hline & EgaSeed $_{2}$ & 61.5 & 56.6 & 53.3 & 45.9 & 54.3 \\
\hline & Mean & 62.3 & $\mathbf{5 8 . 5}$ & 53.3 & 47.0 & $\mathbf{5 5 . 3}$ \\
\hline & EgaSeed $_{1}$ & 48.0 & 45.0 & 40.9 & 36.1 & 42.5 \\
\hline & EgaSeed $_{2}$ & 45.8 & 41.3 & 39.2 & 33.6 & 40.0 \\
\hline & Mean & 46.9 & 43.1 & 40.0 & 34.8 & \\
\hline \multicolumn{7}{|c|}{ LSD $_{0.05}$ for } \\
\hline \multicolumn{2}{|c|}{ Genotypes (Gn.) } & $\mathrm{NS}$ & \multicolumn{2}{|c|}{ Gn. X Gy. } & 7.9 & \\
\hline \multicolumn{2}{|c|}{ Gamma rays $(\mathbf{G y})}$. & 5.8 & \multicolumn{2}{|c|}{ Gy. X Mos. } & NS & \\
\hline \multicolumn{2}{|c|}{ Months (Mos.) } & 5.2 & \multicolumn{2}{|c|}{ Gn. X Mos. } & 7.4 & \\
\hline \multicolumn{2}{|c|}{ Gn. X Gy. XMos. } & 24.0 & & & & \\
\hline
\end{tabular}




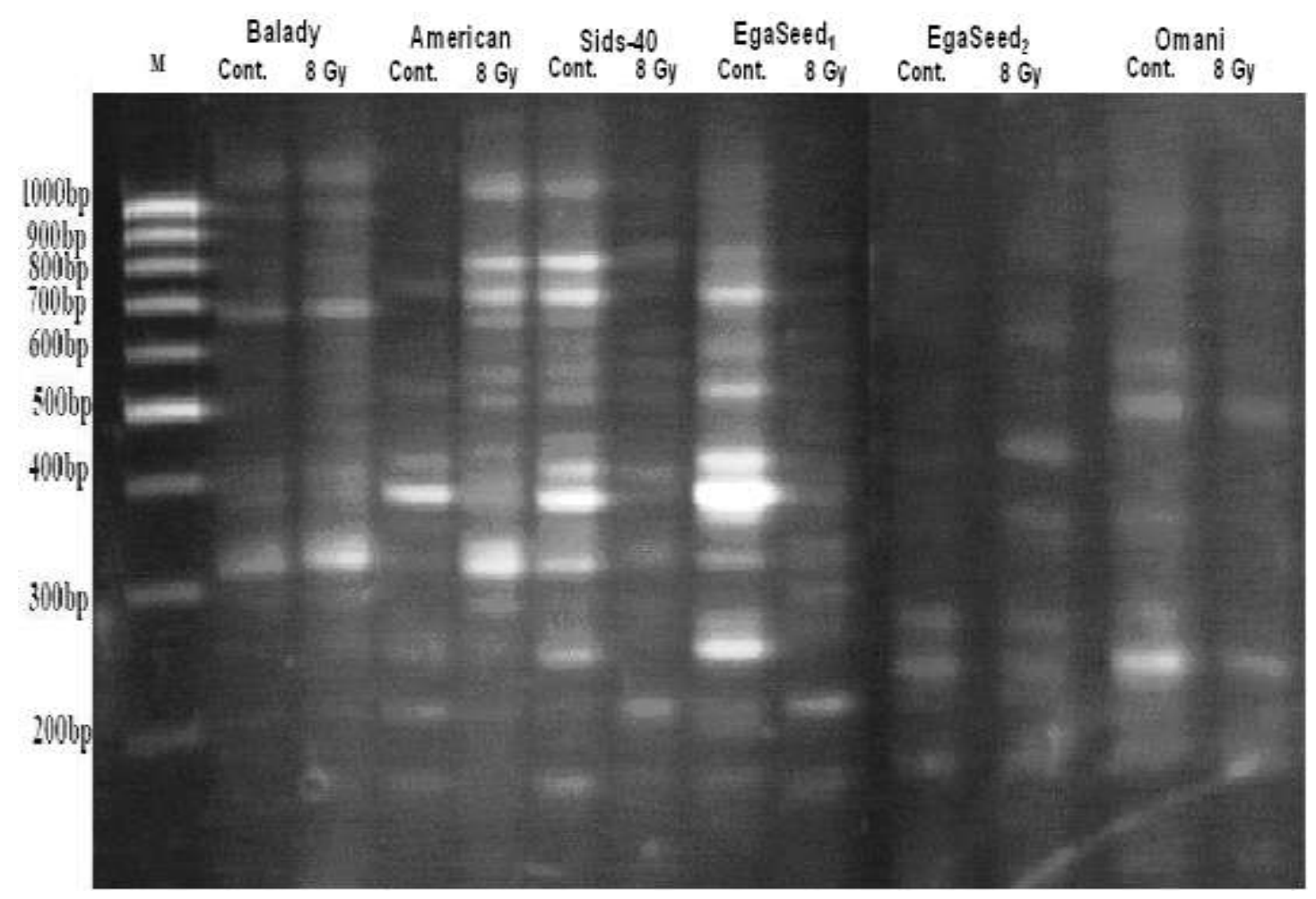

Plat (1): Random amplified polymorphic DNA analysis (RAPD) showing the effect of gamma ray doses (8 GY. and the unirradiated control) on plant genomic DNA of six garlic genotypes for the primer 5’ AGG TGA CCG T 3'(Op-B17)

Table (9): Percentage of bulblet weight loss during storage at $25^{\circ} \mathrm{C}$ of four garlic genotypes (cultivars Balady, American, and Omani as well as Sids-40 clone) as affected by gamma ray doses.

\begin{tabular}{|c|c|c|c|c|c|c|}
\hline \multirow{2}{*}{$\begin{array}{c}\text { Months after } \\
\text { culture }\end{array}$} & \multirow{2}{*}{$\begin{array}{c}\text { Gamma } \\
\text { ray doses }\end{array}$} & \multicolumn{4}{|c|}{ Bulblets weight loss (\%) } & \multirow{2}{*}{ Mean } \\
\hline & & Balady & American & Omani & Sids-40 & \\
\hline \multirow{3}{*}{ One month } & 0 Gy. & 26.6 & 30.9 & 28.1 & 36.5 & 30.5 \\
\hline & 8 Gy. & 19.5 & 26.9 & 24.9 & 29.9 & 25.3 \\
\hline & Mean & 23.1 & 28.9 & 26.5 & 33.2 & 27.9 \\
\hline \multirow{3}{*}{ Two months } & 0 Gy. & 37.4 & 43.4 & 39.4 & 44.7 & 41.2 \\
\hline & 8 Gy. & 24.0 & 39.0 & 38.4 & 39.0 & 35.1 \\
\hline & Mean & 30.1 & 41.2 & 38.9 & 41.5 & 38.2 \\
\hline \multirow{3}{*}{ Three months } & 0 Gy. & 47.5 & 50.0 & 50.3 & 57.2 & 50.3 \\
\hline & 8 Gy. & 35.4 & 47.9 & 46.9 & 49.4 & 44.9 \\
\hline & Mean & 41.5 & 49.0 & 48.6 & 53.3 & 48.1 \\
\hline \multirow{6}{*}{ Four months } & 0 Gy. & 49.6 & 57.7 & 51.0 & 58.7 & 54.2 \\
\hline & 8 Gy. & 39.2 & 49.5 & 47.6 & 50.9 & 46.8 \\
\hline & Mean & 44.4 & 53.6 & 49.3 & 54.8 & 50.5 \\
\hline & 0 Gy. & 40.3 & 45.5 & 42.2 & 49.3 & 44.3 \\
\hline & $8 \mathrm{~Gy}$. & 29.6 & 40.9 & 39.4 & 42.3 & 38.0 \\
\hline & Mean & 34.9 & 43.2 & 40.8 & 45.8 & \\
\hline \multicolumn{7}{|c|}{ LSD $_{0.05}$ for } \\
\hline \multicolumn{2}{|c|}{ Genotypes (Gn.) } & 4.9 & Gn. X Gy. & & 6.0 & \\
\hline
\end{tabular}


The effect of gamma ray dose $8 \mathrm{~Gy}$ on the genetic polymorphism of Balady cv., was observed as five new bands viz., 1118, 991, 690, 331 and 174 bp while the unirradiated Balady cv. (0 Gy) had three other different bands, namely 1109, 680 and 327 bp. Also the irradiated cv. American showed eight bands which were completely different from their unirradiated control; the new bands were 1073, $808,725,564,520,389,327$ and $292 \mathrm{pb}$. The unirradiated control of American cv. showed only six bands, viz, 744, 391, 329, 261, 220 and $170 \mathrm{pb}$. Meanwhile, the RAPD analysis of irradiated Sids40 clone with the same dose of $8 \mathrm{~Gy}$, showed five new bands having the molecular size of 846,417 , 336, 223 and $128 \mathrm{bp}$. These bands were different from the control ( $0 \mathrm{~Gy}$ ) which had nine bands, namely 1082, 815, 725, 532, 420, 387, 329, 259 and $170 \mathrm{bp}$. On the other hand, irradiated EgaSeed $_{1}$ clone showed six bands; only one of them was similar to the unirradiated control which was $391 \mathrm{bp}$ and the other ones were 862, 344, 304, 225 and $170 \mathrm{bp}$. Also, the unirradiated control showed eight additional different bands viz., 725, 610, 540, 433, 333, 262, 220 and 174 bp. Regarding the irradiated EgaSeed $_{2}$ clone, it showed eight bands, two of them were similar to the control viz., 235 and 405 bp. Moreover, the irradiated cv. Omani showed five bands, two of which were similar to the unirradiated control, viz. 242 and $377 \mathrm{bp}$ whereas the other three bands were different viz. 1086, 658 and 307 bp. Also, the unirradiated control showed four additional different bands $v i z, 1071,744,658$ and 516 bp.

\section{DISCUSSION \\ 4.1. Effect of gamma irradiation on in vitro bulblet formation}

In the present investigation, after cold treatment $\left(4-5^{\circ} \mathrm{C}\right)$ of cloves for 60 days and culturing the divisions of shoot basal plate explants on bulblets formation media (MS +0.1 $\mathrm{mg} / \mathrm{l} \mathrm{BA}+120 \mathrm{~g}$ sucrose $+5 \mathrm{~g}$ charcoal), little bulblets began to be formed 30 days after culture and with the progress of time, they reached their maximum number 40 days after culture. Bulblets were formed due to the stimulative effect of the depression of the apical dominance when shoot basal plates were injured or surgically separated to initiate the auxiliary bud formation in the basal clove parts. These results matched the findings of Nagakubo et al. (1993) who mentioned that bulbling can be completed two months after culture and this only occurred after the pretreatment of garlic cloves with low temperature for 2 months before culture.

The protocol which is described in the present study resulted in 100\% microbulblets production with all cultivars under study. The present results are in agreement with those of Nagakubo et al., (1993) and Barandiaran et al., (1999) who found that all the used genotypes were able to produce bulblets, but disagree with Ravnikar et al. (1995) who found that some of the used genotypes need complex additions like jasmonic acid, for bulblets production and the bulblets diameter was $4 \mathrm{~mm}$ or larger in diameter. Generally, bulblets produced in the present study from in vitro cloves culture were single ones. These results prove with those of Nagakubo et al., (1993).

Regarding the effect of gamma irradiation on bulblet production, the present results indicated that gamma rays at high doses i.e., 10, 12 and 14 Gy markedly reduced the number, diameter and weight of bulblets. The present results are in agreement with those obtained by Sklyar, (1973) and Zhen, (1998) who indicated that 10 Gy dose is the critical dose for garlic. Accordingly, the doses of 12 and $14 \mathrm{~Gy}$ were excluded for the $\mathrm{EG}_{1}$ and $\mathrm{EG}_{2}$ clones and the low dose of $3 \mathrm{~Gy}$ was added. The dose of 3 Gy has a stimulatory effect on the number and diameter of bulblet, while the dose of 5 Gy stimulated bulblet fresh weight. These results also confirm by Al-Safadi et al. (2000) on potatoes that were irradiated and in vitro cultured for tuber formation. They found that the low dose of $2.5 \mathrm{~Gy}$ increased the number of microtubers, while the the doses 10 and 15 Gy significantly decreased number of microtubers. This difference in our study may be due to the differences between garlic genotypes or cloves which were dormant or nondormant. It may be concluded that DNA was sensitive to radiation with $10 \mathrm{~Gy}$ in nondormant garlic clove. Hence, 8 Gy was used after that to induce mutations with cultivars Balady, American, and Omani as well as Sids-40 clone because of the satisfactory number of the obtained bulblets.

\subsection{Effect of gamma irradiation on the storage ability of in vitro bulblets}

The physiology of the bulb interacts with the environment and affects bulb storage. The weight loss can not be explained by environmental factors alone (Vazquez-Barrios et al., 2006). After natural 
Table (10): Effect of gamma irradiation (8 Gy) on plant genomic DNA of six garlic genotypes (cultivars Balady , American and Omani (Om) as well as Sids-40, EgaSeed ${ }_{1}$ and EgaSeed 2 clones).

\begin{tabular}{|c|c|c|c|c|c|c|c|c|c|c|c|c|c|}
\hline & & \multicolumn{12}{|c|}{ Genotypes with gamma doses } \\
\hline No. & bp & \multicolumn{2}{|c|}{ Balady } & \multicolumn{2}{|c|}{ American } & \multicolumn{2}{|c|}{ Sids-40 } & \multicolumn{2}{|c|}{ EgaSeed $_{1}$} & \multicolumn{2}{|c|}{ EgaSeed $_{2}$} & \multicolumn{2}{|c|}{ Omani } \\
\hline & & cont. & $8 \mathrm{~Gy}$ & cont. & 8 Gy & cont. & 8 Gy & cont. & $8 \mathrm{~Gy}$ & cont. & $8 \mathrm{~Gy}$ & cont. & $8 \mathrm{~Gy}$ \\
\hline 1 & 1350 & & & & & & & & & + & & & \\
\hline 2 & 1300 & & & & & & & & & & & & \\
\hline 3 & 1118 & & + & & & & & & & & & & \\
\hline 4 & 1109 & + & & & & & & & & & & & \\
\hline 5 & 1086 & & & & & & & & & & & & + \\
\hline 6 & 1082 & & & & & + & & & & & & & \\
\hline 7 & 1073 & & & & + & & & & & & & & \\
\hline 8 & 1071 & & & & & & & & & & & + & \\
\hline 9 & 1007 & & & & & & & & & & + & & \\
\hline 10 & 991 & & + & & & & & & & & & & \\
\hline 11 & 862 & & & & & & & & + & & & & \\
\hline 12 & 846 & & & & & & + & & & & & & \\
\hline 13 & 815 & & & & & + & & & & & & & \\
\hline 14 & 808 & & & & + & & & & & & & & \\
\hline 15 & 795 & & & & & & & & & & + & & \\
\hline 16 & 748 & & & & & & & & & & & + & \\
\hline 17 & 744 & & & + & & & & & & & & & \\
\hline 18 & 725 & & & & + & + & & + & & & & & \\
\hline 19 & 690 & & + & & & & & & & & & & \\
\hline 20 & 680 & + & & & & & & & & & & & \\
\hline 21 & 665 & & & & & & & & & & & + & \\
\hline 22 & 658 & & & & & & & & & & & & + \\
\hline 23 & 646 & & & & & & & & & & & & \\
\hline 24 & 610 & & & & & & & + & & & & & \\
\hline 25 & 600 & & & & & & & & & & + & & \\
\hline 26 & 564 & & & & + & & & & & & & & \\
\hline 27 & 540 & & & & & & & + & & & & & \\
\hline 28 & 532 & & & & & + & & & & & & & \\
\hline 29 & 520 & & & & + & & & & & & & & \\
\hline 30 & 516 & & & & & & & & & & + & + & \\
\hline 31 & 433 & & & & & & & + & & & & & \\
\hline 32 & 420 & & & & & + & & & & & & & \\
\hline 33 & 417 & & & & & & + & & & & & & \\
\hline 34 & 405 & & & & & & & & & + & + & & \\
\hline 35 & 391 & & & + & & & & + & + & & & & \\
\hline 36 & 389 & & & & + & & & & & & & & \\
\hline 37 & 387 & & & & & + & & & & & & & \\
\hline 38 & 377 & & & & & & & & & & & + & + \\
\hline 39 & 372 & & & & & & & & & + & & & \\
\hline 40 & 370 & & & & & & & & & & + & & \\
\hline 41 & 344 & & & & & & & & + & & & & \\
\hline 42 & 336 & & & & & & + & & & & & & \\
\hline 43 & 333 & & & & & & & + & & & & & \\
\hline 44 & 331 & & + & & & & & & & & & & \\
\hline 45 & 329 & & & + & & + & & & & & & & \\
\hline 46 & 327 & + & & & + & & & & & & & & \\
\hline 47 & 312 & & & & & & & & & & + & & \\
\hline 48 & 307 & & & & & & & & & + & & & + \\
\hline 49 & 304 & & & & & & & & + & & & & \\
\hline 50 & 292 & & & & + & & & & & & & & \\
\hline 51 & 262 & & & & & & & + & & & & & \\
\hline 52 & 261 & & & + & & & & & & & & & \\
\hline 53 & 259 & & & & & + & & & & & & & \\
\hline 54 & 242 & & & & & & & & & & & + & + \\
\hline 55 & 235 & & & & & & & & & + & + & & \\
\hline 56 & 225 & & & & & & & & + & & & & \\
\hline 57 & 223 & & & & & & + & & & & & & \\
\hline 58 & 220 & & & + & & & & + & & & & & \\
\hline 59 & 174 & & + & & & & & + & & & & & \\
\hline 60 & 170 & & & + & & + & & & + & & & & \\
\hline 61 & 128 & & & & & & + & & & & & & \\
\hline Total & number & 3 & 5 & 6 & 8 & 9 & 5 & 9 & 6 & 5 & 8 & 6 & 5 \\
\hline
\end{tabular}


drying in open air for 1-2 days, the bulblets were compact and hard (the subjective firmness was evaluated by manually squeezing bulblets between the fingers) and no more water was lost. Moreover, no visible sprouting occurred, it was healthy, clean, well developed and retained outer skin under conditions of the incubation room (25 $\left.\pm 2^{\circ} \mathrm{C}\right)$. The results are in agreement with Vazquez-Barrios et al. (2006) who mentioned that storage at $20^{\circ} \mathrm{C}$ was similar to at zero ${ }^{\circ} \mathrm{C}$, but disagreed with Mann and Lewis (1956) who found that it is very important to store bulb at zero ${ }^{\circ} \mathrm{C}$. The variations among the results may be due to the pretreatment of the in vitro bulblets in this study before storage (with 1:1 Benlite: esolex) and the environmental condition, i. e., good air circulation, the suitable humidity as well as the temperature in the incubation room. Besides, this may be due to the physiological state of the bulblets, i.e., size of the stored bulblets may cause this difference, or it may be caused by the different behavior of the genotypes. Finally, the cool dry air and good low respiration rate are suitable for garlic storage in the incubation room.

\subsection{Effect of gamma irradiation on the genetic variation of in vitro bulblets}

The effect of irradiation dose of $8 \mathrm{~Gy}$ on the DNA banding pattern was shown by RAPD analysis. The differences in the banding pattern at the dose of 8 Gy compared with the control, support the previous data in which gamma rays caused genetic changes in garlic plants. These results are in agreement with those obtained by many investigators, who indicated that in vitro genetic changes may be due to the culture conditions or the effect of gamma ray, as the most effective agents for mutation induction (Sklyar, 1973; Anonymous, 1986 and 1987; Maluszynski et al., 1995; Alvarez and Delgado, 1996 and Zhen, 1998).

\section{REFERENCES}

Al-Safadi B., Ayoubi Z. and Jawdat D. (2000). Effect of gamma irradiation on potato microtuber in vitro. Plant Cell Tiss. Org. Cult., 61:183-187.

Alvarez R.B. and Delgado de la Floa F. (1996). Evaluation of an M1 population of garlic (Allium sativum L.) cv. Morado Arequipeno irradiated with gamma rays. Rivista de Agricoltura Subtropicale e Tropicale, 90:369377.

Anonymous (1986). In vitro technology for mutation breeding. International Atomic Energy Agency. Vienna, IAEA, TECDOC. $392,58 \mathrm{pp}$.
Anonymous (1987). Improvement of root and tuber crops by induced mutation. International Atomic Energy Agency. Vienna, IAEA, TECDOC. 318: 1-2.

Barandiaran X., Martin N., Alba C., RodriguezConde M.F., Pietro A.d. and Martin J. (1999). An efficient method for the in vitro management of multiple garlic accessions. In Vitro Cell. Dev. Biol. Plant., 35:466-4.69.

Block E. (1985). The chemistry of garlic and onions. Sci. Am., 252:114-119.

Dedul F.A., Kadzhaya A.S. and Davituri M.I. (1985). Effect of radiation on onion and garlic plants followed irradiation of the bulbs. Radiotsionnyi. Mutagenz Vegetativno Razmnozhaemykh Rasleinii, 151-154. (C. F. Online CBI Abst.)

Dunstan D. I. and Short K.C. (1977). Improved growth tissue culture of onion Allium cepa. Physio. Plant.41:70-72.

Ebi M., Kasai N. and Masuda K. (2000). Small inflorescence bulbils are best for micropopagation and virus elimination in garlic. HortSci., 35:735-737.

Gomez K.A. and Gomez A. A. (1984). Statistical Procedure for Agricultural Research. International Rice Research Institute, $2^{\text {nd }} \mathrm{Ed}$. John Wiley and Sons Inc. New-York, 680 pp.

Haque M.S., Wada T., and Hattori K. (1997). Frequency shoot regeneration and plantlet formation from root tip of garlic. Plant Cell Tiss. Organ Cult. 50:83-89.

Hussey G. (1978). In vitro propagation of onion Allium cepa by axillary and adventitious shoot proliferation. Sci. Hortic. 9:227-236.

Maluszynski M., Ahloowalia B.S. and Sigurbjhornsam B. (1995). Application of in vivo and in vitro mutation technique for crop improvement. Euphytica, 85:303-315.

Mann, L.K. and Lewis D.A. (1956). Rest and dormancy in garlic. Hilgardia, 26:161-189.

Mohamed-Yasseen Y., Splittstoesser W.E. and Litz R.E. (1992). Regeneration of onion (Allium cepa) bulb in vitro. Plant Growth Reg. Soc. Amer., 20:76-82.

Mohamed-Yasseen Y., Splittstoesser W.E. and Litz R.E. (1994). In vitro shoot proliferation and production of sets from garlic and shallot. Plant Cell. Tiss. Organ Cult., 36:243-247.

Mohamed-Yasseen Y. Barringer S.A. and Splittstoesser W.E. (1995). In vitro bulb production from Allium spp. In Vitro Cell. Dev., 31:51-52.

Murashige T. and Skoog F. (1962). A revised medium for rapid growth formation and 
bioassays with tobacco tissue cultures. Physiol. Plant, 15: 473-497.

Nagakubo T., Nagasawa A. and Ohkawa H. (1993). Micropropagation of garlic through in vitro bulblet formation. Plant Cell Tiss. Org. Cult., 32:175-183.

Nagakubo T., Takaichi M. and Oeda K. (1997). Micropropagation of Allium sativum $\mathrm{L}$. (Garlic). In: Bajaj TPS (ed). Biotech. in Agri. and Forest. 39. Springer Verlag Berline, Heidelberg. New York, p. 3-19.

Nagasawa A. and Finer J.J. (1988). Induction of morphogenic callus cultures from leaf tissue of garlic. HortSci., 23: 1068-1070

Novak F. J. (1990). Allium tissue culture. In: Rabinowitch, H. D.; Brewster, J. L., eds. Onions and Allied Crops, Vol. 1. Boca Raton, FL: CRC Press, 233-250.

Perez T.S. and Labrada A. (1988). Values of GR50 for crop species in Cuba. Ciencia de la Agricultura. 33:146-149.

Ravnikar M., Plaper I., Kaltnekar P., Paradiz J. and Zel J. (1995). The effect of jasmonic acid on garlic meristem culture. Acta. Pharm., 45:237-239.

Sklyar G.E. (1973). The induction of somatic chemical and radiation mutants in garlic. Bioliz.Issled. Pri Selekisii Rast. Na Gelerozis, 90-95.

Sumi S.I., Tsunefoshi T., Suzuki A. and Ayab M. (2001). Development and establishment of practical tissue culture methods for production of virus free garlic seed bulbs, a novel field cultivation system and convenient methods for defecting garlic infection viruses. Plant Biotech., 18:179-190.

Takagi H. and Qu Y. (1995). Effect of light quality, photoperiod and cold treatment on in vitro bulbling of garlic shoot tip. Acta Hortic. 393:181-188.

Ucman R. Zel J. and Ravnikar M. (1998). Thermotherapy in virus elimination from garlic:Influnces on shoot multiplication from meristems and bulb formation in vitro. Scientia Hort. 73:193-202.

Vazquez-Barrios M.E., Lopez-Echevarria G., Mercado-Silva E., Castano-Tostado E. and Leon-Gonzalez F. (2006). Study and prediction of quality changes in garlic $\mathrm{cv}$. Perla (Allium sativum L.) stored at different temperatures. Sci. Hort., 108:127-132.

Vuylsteke R. and Ortiz R. (1996). Field performance of conventional virsus in vitro propagules of plantain (Musa spp. AAB group). HortSci., 31:862-865.

Williams J.G.K., Kubelik A.R., Livak K.J., Rafalski J.A. and Tingey S.V. (1990). DNA polymorphisms amplified by arbitrary primers are useful as genetic markers. Nucleic Acids Research, 18: 6531-6535.

Xeu H. M., Araki H., Shi L. and Yakuwa T. (1991). Somatic embryogenesis and plant regeneration in basal plate and receptacle derived-callus cultures of garlic (Allium sativum L.). J. Jap. Soc. Hort. Sci., 60:627634.

Zet I., Debljak N., Ucman R. and Ravinkar M. (1997). The effect of jasmonic acid, sucrose and darkness on garlic (Allium sativum L. cv. Ptujskijes enski) bulb formation in vitro. In vitro Cell Dev. Biol. Plant, 33:231-235.

Zhen H. (1998). Effect of garlic (Allium sativum L.) leaf callus irradiated with gamma ray on globular body formation. Act. Agri. Shanghi., 14:21-32.

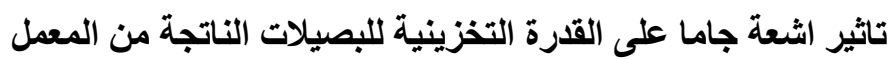

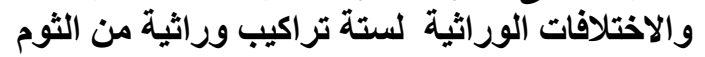

$$
\begin{aligned}
& \text { سيد فتحى السيد ـ احمد على غريب ـ محمه رفتت الشامى* ـ نرمين عبد التواب المنادى عبد الودود* }
\end{aligned}
$$

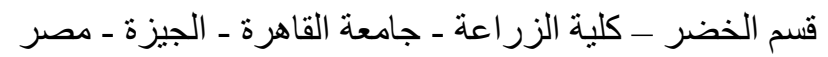

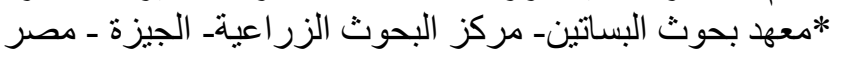

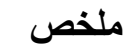

$$
\begin{aligned}
& \text { تم اجر اء هذا البحث فى معمل زر اعة الانسجة التابع لقسم بحوث البطاطس و الخضر خضرية التكاثر - بمعهد }
\end{aligned}
$$

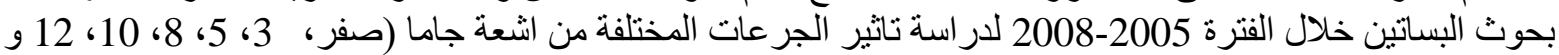

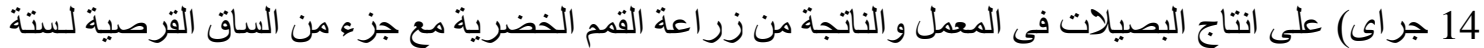

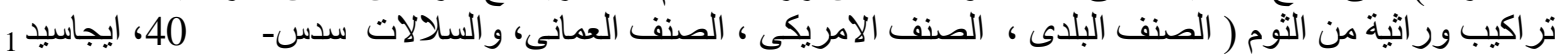

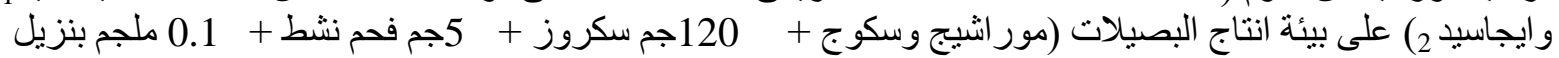

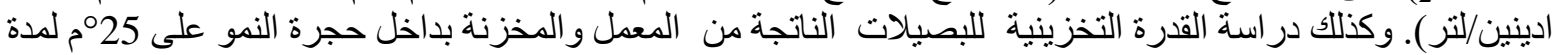




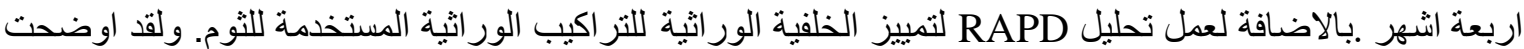

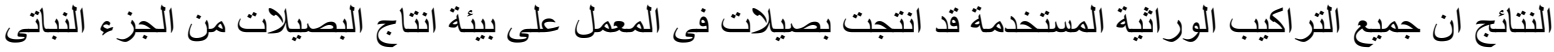

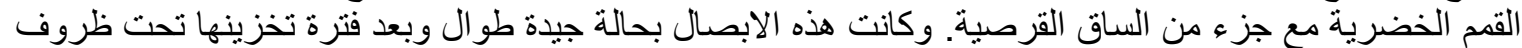

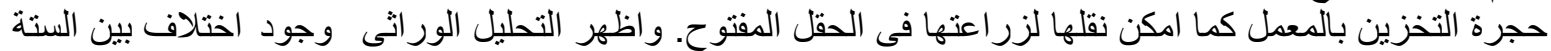

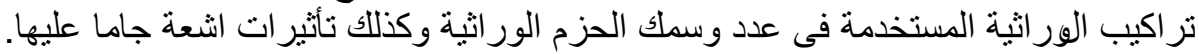

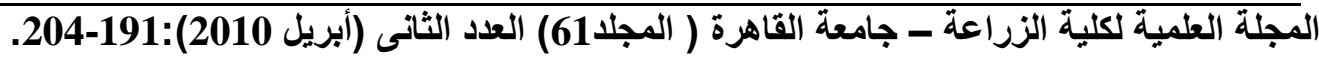

